\title{
Diversity of aquatic macrophytes in Balili River, La Trinidad, Benguet, Philippines as potential phytoremediators
}

\author{
JONES T. NAPALDET ${ }^{1, \boldsymbol{v}}$, INOCENCIO E. BUOT JR., ${ }^{2, v}$ \\ ${ }^{1}$ Department of Botany, University of the Philippines Los Baños (UPLB), Instructor, Biology Department, Benguet State University, Km. 6, La Trinidad, \\ Benguet 2601, Philippines. ‘email: jtnapaldet@up.edu.ph. \\ ${ }^{2}$ Institute of Biological Sciences, University of the Philippines, Los Baños 4031, Philippines. "email: iebuotjr@upou.edu.ph.
}

Manuscript received: 6 January 2018. Revision accepted: 20 March 2019.

\begin{abstract}
Napaldet JT, Buot JR IE. 2019. Diversity of aquatic macrophytes in Balili River, La Trinidad, Benguet, Philippines as potential phytoremediators. Biodiversitas 20: 1048-1054. Phytoremediation, an emerging, low-cost, aesthetically pleasing technology, is now being eyed for restoration of Balili River, Philippines. But first, there is a need to identify plants ideal for its phytoremediation. Macrophytes in the main stream, Bolo Creek and Mamaga Creek of Balili River were inventoried in this study with focus on determining macrophytes that were local, dominant (=fast growing), have high biomass and deep root systems - traits ideal for phytoremediation. A total of 38 species of macrophytes under 37 genera and 19 families were inventoried. This number is much higher than the previous inventory which recorded only 9 species. Consequently, diversity indices recorded in this study is much higher. The difference could be attributed to the time of sampling wherein the previous inventory was done in July, a rainy month, in contrast with this in April, the summer month at which the river is at its lowest level. At this period, much of the littoral zone is exposed for colonization of plants known to be easily dispersed and germinate such as Asteraceae species. In terms of species richness, family Asteraceae was the most represented with 11 species but in terms of dominance, the story was different. Dominant macrophytes of Balili River were species of family Poaceae (Pennisetum purpureum, Eleusine indica and Cynodon dactylon), Amaranthaceae (Amaranthus spinosus and Alternanthera sessilis), Solanaceae (Solanum americanum) and Commelinaceae (Commelina diffusa). Local macrophytes with potential for phytoremediation were P. purpureum, E. indica, A. spinosus and S. americanum.
\end{abstract}

Keywords: Balili River, diversity indices, macrophytes, phytoremediation

\section{INTRODUCTION}

Balili River is an important water resource of Baguio City and La Trinidad but like most urban rivers, it suffers from severe pollution due to indiscriminate waste dumping. It was classified as Class A by Environmental Management Bureau (EMB-CAR) but is practically a dead river during summer months. The excessive pollution of the river was usually blamed on the densely populated city of Baguio, with the river previously being tagged as "toilet bowl of Baguio City". A study by the City Environment and Parks Management Office (CEPMO) of Baguio City showed that half of the city's population lives within the Balili watershed area, contributing the most waste. The river was included in the DENR's 2003 Pollution Report as one of the 15 "biologically dead" rivers among the 94 principal river basins in the country (Aro 2011; Palangchao 2015).

Several rehabilitation efforts had been conducted in Balili River as early as April 1999 with the launching of Balili River Summit, followed by several clean-up activities, information campaign, etc. until finally its designation as a Water Quality Management Area in 2015. But amidst all these efforts, the river still remains polluted up to present. Thus, alternative method of clean-up such as phytoremediation is timely and worth investigating. In fact, DENR-CAR was eyeing phytoremediation to revive the Balili River and other rivers in Cordillera (See 2014). But first, there is a need to identify plants in the area ideal for phytoremediation. Usual plants used in phytoremediation such as Typha spp. and Phragmites autralis (Coppini and Masi 2006; Akratos and Tsihrintzis 2007; Hoddinott 2006) do not occur in the river but other macrophytes were observed growing robustly in the river. These macrophytes were the aim of this study for inventory and documentation with special focus on plants with ideal traits for phytoremediation. According to Moffat (1995) and EPA (2000), traits for phytoremediation include local, dominant plants (=fast growing), with high biomass and deep root systems.

Results of this study would also contribute to the country's effort of documenting its biodiversity. In a review conducted by Langenberger (2004), limited floral diversity had been conducted in the country and these primarily focus on tress and woody plants. He lamented the poor representation of Philippine vegetation in international research compared to other tropical rainforest areas. Smaller trees and other life forms were usually neglected although they account for the bulk of species richness. Moreover, ecosystems other than forest were not given much emphasis in floral assessment studies such as river ecosystems. Very few studies were conducted on macrophyte diversity amidst the importance of these plants. Aquatic macrophytes which include mosses, liverworts, larger algae and vascular aquatic plants, play an important role in structuring communities in aquatic environments by providing physical structure, increasing habitat complexity 
and heterogeneity and affecting various organisms like invertebrates, fishes and waterbirds (Thomaz and da Cunha 2010).

\section{MATERIALS AND METHODS}

Local plants growing along the riparian zone were assessed using quadrat method and harvest method from March to April 2018, the summer time at which the river is most polluted. The plants present at this time are the species most likely pollution-tolerant, a trait essential for phytoremediation. Quadrat method was used to identify the dominant plants while harvest method was used to identify species with high biomass, a trait ideal for phytoremediation. In the harvest method, the underground organs of the plant were also included. Three (3) sampling stations were established along the river; one in the mainstream and one each in two main tributaries of the river in La Trinidad side namely Bolo Creek and Mamaga Creek (refer to Figure 1). In each station, 5 quadrats measuring $1 \mathrm{~m}^{2}$ each $(1 \mathrm{x} 1 \mathrm{~m})$ were used both for population counts and harvest method. Plants inventoried were identified using several taxonomic references (Pancho and
Obien 1995; Pancho and Gruezo 1983, 2006, 2009, 2012; Co's Digital Flora), and voucher specimens were prepared.

Density, frequency and dry biomass were the major parameters measured. These were determined using the following formulas:

$$
\text { Density }=\frac{\text { ni }(\text { number of individual of species } \mathrm{i})}{\text { Total area sampled }\left(\mathrm{m}^{2}\right)}
$$

Frequency $(\%)=\underline{\mathrm{Ji} \text { (number of quadrat where the species occur) }} \times 100$ $\mathrm{K}$ (Total number of quadrat)

Relative Density $=\underline{\text { Di (Density of species i) }} \times 100$ Total D of all species

Relative Frequency $=\quad$ Fi (Frequency of species i) $\times 100$ Total F of all species

Relative Biomass $=\underline{\text { Biomass of Species i }} \times 100$

Total biomass of all species

Importance Value $=\underline{\mathrm{RDi}+\mathrm{RFi}+(2) \mathrm{RBi}}$

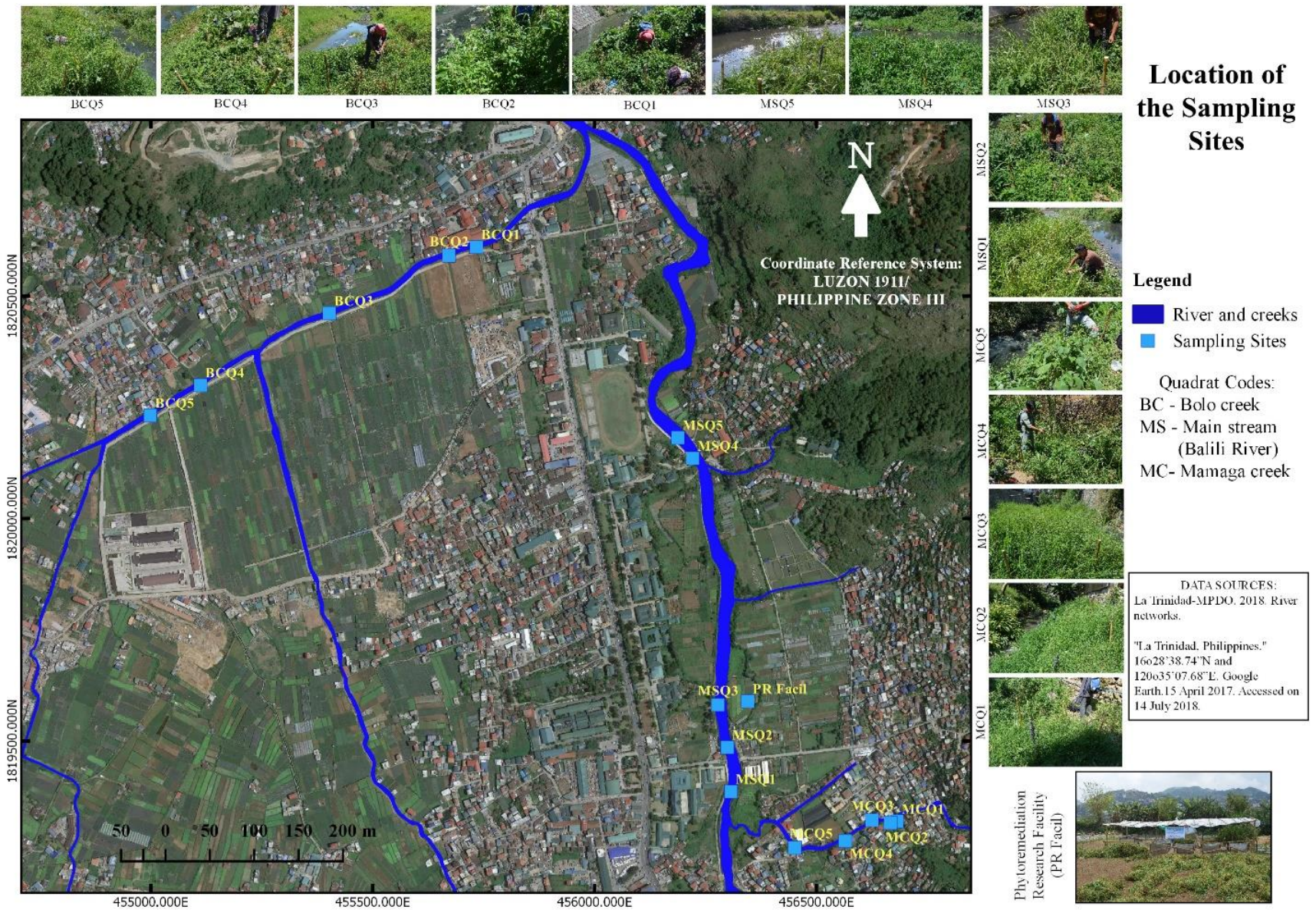

Figure 1. Close-up map of Balili River River, Philippines showing the sampling areas 
Diversity indices such as Shannon-Wiener's, Margalef's and Simpson's were also computed and compared among the sampling stations. Shannon-Wiener diversity index takes into account species richness and the proportion of each species within the local community. It also accounts evenness or the distribution of individuals among the species. It was calculated as follows (ShannonWiener 1949):

$\mathrm{H}=\sum \mathrm{p} i(\ln \mathrm{p} i)$

Where:

$\mathrm{H}$ : Shannon-Wiener diversity index

pi : Number of individuals of species i/ total number of samples

$\mathrm{S}:$ Number of species or species richness

$\mathrm{E}: \mathrm{H} / \mathrm{H}_{\max }$

E: Evenness

$\mathrm{H}_{\max }($ maximum diversity possible) $: \ln (\mathrm{N})$

Simpson's index is the complimentary of evenness. It is the common measure of dominance and was computed as follows:

$$
\mathrm{D}: \frac{\sum \mathrm{n} i(\mathrm{n} i-1)}{\mathrm{N}(\mathrm{N}-1)}
$$

Where:

ni : total individual of species $\mathrm{i}$

$\mathrm{N}$ : total number of individual of all species

On the other hand, Margalef's index is simpler. It was computed as:

$\mathrm{R}=(\mathrm{S}-1) / \ln (\mathrm{N})$

Where:

$\mathrm{R}$ : richness

$\mathrm{S}:$ :\# of species

$\mathrm{N}$ : \# of individuals (of all species)

To compare the diversity between sampling stations, Jaccard index of similarity was used. It was simply computed as:

$\mathrm{J}=(\mathrm{Sc}) /(\mathrm{Sa}+\mathrm{Sb}+\mathrm{Sc}) \times 100$

Where:

Sc: number of species common to the two samples

Sa: number of species unique to station a

$\mathrm{Sb}$ : number of species unique to station $\mathrm{b}$

\section{RESULTS AND DISCUSSION}

A total of 38 species of macrophytes under 37 genera and 19 families were inventoried in Balili River. In the main stream (Table 1), 26 species were determined while 12 in Mamaga Creek (Table 2) and 25 in Bolo Creek (Table 3). The low species richness in Mamaga could be attributed to highly disturbed state of the creek wherein much of the littoral zone is cemented at both sides; thus, discouraging growth of plants. Also, this could also be attributed to the dominance of Cynodon dactylon which cover much of the creek and thus preventing growth of other plants. The species richness in the main stream and Bolo Creek was much higher than the nine (9) species recently reported by Napaldet and Bout (2017) for Balili River. This discrepancy could be directly attributed to the time of sampling. The earlier sampling by Napaldet and Buot (2017) was done in July, a rainy month, while this study was conducted in April, the time at which the river is at its lowest level. At this period, much of the littoral zone was exposed for plant colonization and sure enough, the opportunistic plants known to be easily dispersed and germinate such as species from family, 'Asteraceae'. Much of these Asteraceae were absent during the sampling of Napaldet and Buot (2017) and as these were annual expected not to last long and be washed off during rainy season. This agree with the conclusion of Hughes et al. (2007) that in highly disturbed ecosystem like Balili River, species richness could vary significantly in different times.

In terms of species richness, family Asteraceae was the most represented with 11 species followed by Poaceae with 5, Amaranthaceae, Brassicaceae, Cucurbitaceae, Cyperaceae, Polygonaceae and Solanaceae with 2 species each while the rest of the families were represented by a single species (Figure 2). However, in terms of dominance, the story was different (Table 4). The dominant macrophytes of Balili River were species of family Poaceae (Pennisetum purpureum, Eleusine indica and Cynodon dactylon), Amaranthaceae (Amaranthus spinosus and Alternanthera sessilis), Solanaceae (Solanum americanum) and Commelinaceae (Commelina diffusa). All the plants inventoried were emergent plants in the littoral zone that can tolerate water-saturated soil and occasional flooding.

The main stream was dominated by Pennisetum purpureum, Eleusine indica, Amaranthus spinosus, Alternanthera sessilis, Solanum nigrum and Cynodon dactylon. On the other hand, the two tributaries, Bolo and Mamaga Creek, were dominated by 2 to 3 species only. Mamaga Creek was dominated by $C$. dactylon and $A$. sessilis while Bolo Creek by $C$. dactylon, $S$. americanum and $C$. diffusa. Cynodon dactylon usually forms a dense interwoven mat that prevents growth of other plants. Patches dominated by this grass often have very low diversity and were more evident in the two tributaries.

These results reflects habitat heterogeneity at the study sites. The dominance of fewer species in the tributaries could be attributed to the lesser degree of disturbance they experienced compared with the main stream. Greater fluctuation in water flow is readily apparent in the main stream which could change from a gentle riffle to a roaring rapid during heavy rains thus stripping away the vegetations. Another factor is the difference in edaphic condition. The two tributaries, Bolo and Mamaga Creek, predominantly have rocky loamy/clayey substrate that makes the rhizomatous condition of $C$. dactylon very hard to uproot. The main stream, on the other hand, have gravely/ sandy substrate that can be readily disturbed by 
strong water flow. This minimizes the establishment of a allowing growth of other macrophytes and resulting to continuous mat of $C$. dactylon or A. sessilis, thereby greater species richness.

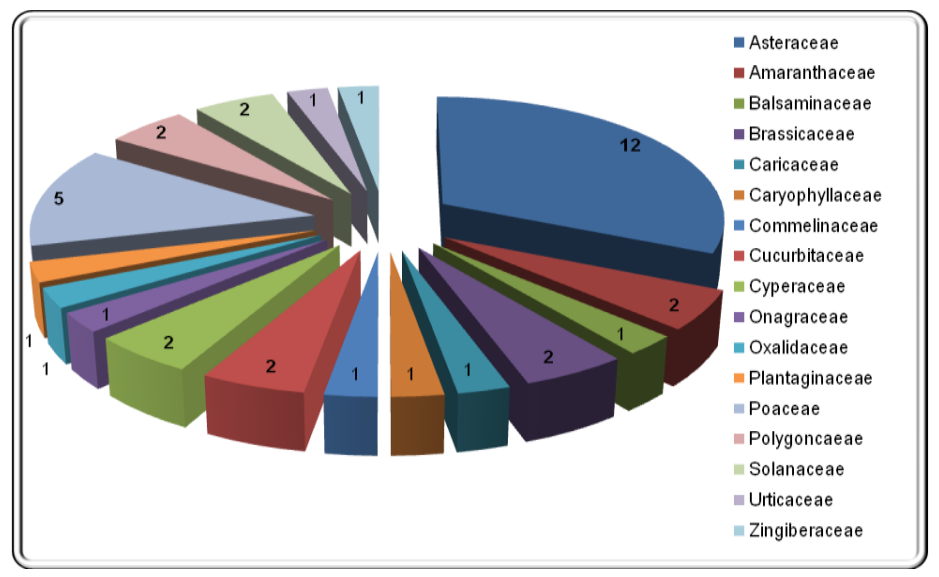

Figure 2. Distribution of aquatic macrophyte species by family

Table 1. The dominant aquatic macrophytes in the main strem, Bolo Creek and Mamaga Creek of Balili River River, Philippines

\begin{tabular}{lclclc}
\hline \multicolumn{1}{c}{ Main stream } & \multicolumn{1}{c}{ Mamaga Creek } & \multicolumn{2}{c}{ Bolo Creek } \\
\hline \multicolumn{1}{c}{ Species } & IV & \multicolumn{1}{c}{ Species } & IV & \multicolumn{1}{c}{ Species } & IV \\
\hline Pennisetum purpureum & 33.95 & Cynodon dactylon & 39.48 & Cynodon dactylon & 26.11 \\
Eleusine indica & 9.67 & Alternanthera sessilis & 26.69 & Solanum americanum & 14.18 \\
Amaranthus spinosus & 8.72 & Brugmansia versicolor & 8.69 & Commelina diffusa & 11.68 \\
Alternanthera sessilis & 8.51 & Crassocephalum crepidioides & 6.16 & Galinsoga parviflora & 6.96 \\
Solanum americanum & 8.39 & Tithonia diversifolia & 5.12 & Alternanthera sessilis & 5.75 \\
Cynodon dactylon & 5.40 & Cyperus involucratus & 2.97 & Bidens pilosa & 4.52 \\
Galinsoga parviflora & 5.16 & Pennisetum purpureum & 2.46 & Amaranthus spinosus & 4.16 \\
Rorippa indica & 5.09 & Paspalum conjugatum & 1.79 & Pennisetum purpureum & 3.76 \\
Crassocephalum crepidioides & 4.13 & Ageratina riparia & 1.74 & Persicaria glabra & 2.85 \\
Ageratum conyzoides & 3.37 & Setaria palmata & 1.72 & Crassocephalum & 2.81 \\
& & & & crepidioides & \\
\hline
\end{tabular}

Table 2. Aquatic macrophytes in the main stream of Balili River River, Philippines

\begin{tabular}{|c|c|c|c|c|c|c|c|c|c|}
\hline $\begin{array}{l}\text { Species name } \\
\end{array}$ & ni & $\mathbf{J i}$ & ODW & Di & $\mathbf{F i}$ & RDWi & RDi & RFi & IV \\
\hline Ageratina riparia (Regel) R.M.King\&H.Rob. & 2 & 1 & 1 & 0.4 & 20 & 0.03 & 0.57 & 1.49 & 0.53 \\
\hline Ageratum conyzoides (L.) L. & 11 & 5 & 45.9 & 2.2 & 100 & 1.45 & 3.12 & 7.46 & 3.37 \\
\hline Alternanthera sessilis (L.)R.Br. ex DC. & 24 & 3 & 360 & 4.8 & 60 & 11.39 & 6.80 & 4.48 & 8.51 \\
\hline Amaranthus spinosus L. & 14 & 5 & 370.9 & 2.8 & 100 & 11.73 & 3.97 & 7.46 & 8.72 \\
\hline Bidens pilosa $\mathrm{L}$. & 2 & 1 & 12.6 & 0.4 & 20 & 0.40 & 0.57 & 1.49 & 0.71 \\
\hline Crassocephalum crepidioides (Benth.) S.Moore & 27 & 3 & 69.6 & 5.4 & 60 & 2.20 & 7.65 & 4.48 & 4.13 \\
\hline Cucurbita maxima Duchesne & 1 & 1 & 5.8 & 0.2 & 20 & 0.18 & 0.28 & 1.49 & 0.54 \\
\hline Cynodon dactylon (L.) Pers. & 16 & 1 & 246 & 3.2 & 20 & 7.78 & 4.53 & 1.49 & 5.40 \\
\hline Cyperus distans L.f. & 7 & 3 & 6.9 & 1.4 & 60 & 0.22 & 1.98 & 4.48 & 1.72 \\
\hline Dichrocephala auriculata (Thunb.) Druce & 3 & 3 & 1.2 & 0.6 & 60 & 0.04 & 0.85 & 4.48 & 1.35 \\
\hline Drymaria cordata (L.) Willd. exSchult. & 1 & 1 & 0.7 & 0.2 & 20 & 0.02 & 0.28 & 1.49 & 0.46 \\
\hline Eleusine indica (L.) Gaertn. & 26 & 4 & 400.6 & 5.2 & 80 & 12.67 & 7.37 & 5.97 & 9.67 \\
\hline Erechtites valerianifolius (Wolf) DC. & 1 & 1 & 48.7 & 0.2 & 20 & 1.54 & 0.28 & 1.49 & 1.21 \\
\hline Galinsoga parviflora Cav. & 20 & 4 & 142.3 & 4 & 80 & 4.50 & 5.67 & 5.97 & 5.16 \\
\hline Ludwigia perennis $\mathrm{L}$. & 1 & 1 & 5.9 & 0.2 & 20 & 0.19 & 0.28 & 1.49 & 0.54 \\
\hline Melothria pendula $\mathrm{L}$ & 2 & 1 & 3.3 & 0.4 & 20 & 0.10 & 0.57 & 1.49 & 0.57 \\
\hline Mikania cordata (Burm.f.) B.L.Rob. & 25 & 2 & 8.2 & 5 & 40 & 0.26 & 7.08 & 2.99 & 2.65 \\
\hline Paspalum conjugatum P.J.Bergius & 1 & 1 & 0.4 & 0.2 & 20 & 0.01 & 0.28 & 1.49 & 0.45 \\
\hline Pennisetum purpureum Schumach. & 103 & 5 & 1567.4 & 20.6 & 100 & 49.59 & 29.18 & 7.46 & 33.95 \\
\hline Persicaria glabra (Willd.) M.Gómez & 8 & 3 & 49.5 & 1.6 & 60 & 1.57 & 2.27 & 4.48 & 2.47 \\
\hline Pilea microphylla (L.) Liebm. & 5 & 1 & 4.1 & 1 & 20 & 0.13 & 1.42 & 1.49 & 0.79 \\
\hline Plantago major $\mathrm{L}$. & 6 & 3 & 82.2 & 1.2 & 60 & 2.60 & 1.70 & 4.48 & 2.84 \\
\hline Pseudognaphalium hypoleucum (DC.) Hilliard \&B.L.Burtt & 1 & 1 & 1.2 & 0.2 & 20 & 0.04 & 0.28 & 1.49 & 0.46 \\
\hline Rorippa indica (L.) Hiern & 32 & 5 & 60.8 & 6.4 & 100 & 1.92 & 9.07 & 7.46 & 5.09 \\
\hline Solanum americanum Mill. & 41 & 5 & 228.8 & 8.2 & 100 & 7.24 & 11.61 & 7.46 & 8.39 \\
\hline Tithonia diversifolia (Hemsl.) A.Gray & 8 & 3 & 16.8 & 1.6 & 60 & 0.53 & 2.27 & 4.48 & 1.95 \\
\hline
\end{tabular}


Table 3. Aquatic macrophytes in Mamaga Creek of Balili River, Philippines

\begin{tabular}{|c|c|c|c|c|c|c|c|c|c|}
\hline $\begin{array}{c}\text { Species name } \\
\end{array}$ & ni & $\mathbf{J i}$ & ODW & Di & $\mathbf{F i}$ & RDWi & RDi & RFi & IV \\
\hline Ageratina riparia (Regel) R.M.King\&H.Rob. & 2 & 1 & 2.8 & 0.4 & 20 & 0.15 & 2.30 & 4.35 & 1.74 \\
\hline Alternanthera sessilis (L.) R.Br. ex DC. & 19 & 5 & 586.7 & 3.8 & 100 & 31.60 & 21.84 & 21.74 & 26.69 \\
\hline Brugmansia versicolor Lagerh. & 3 & 1 & 250.4 & 0.6 & 20 & 13.49 & 3.45 & 4.35 & 8.69 \\
\hline Cynodon dactylon (L.) Pers. & 45 & 4 & 824.5 & 9 & 80 & 44.41 & 51.72 & 17.39 & 39.48 \\
\hline Cyperus involucratus Rottb. & 2 & 2 & 8.3 & 0.4 & 40 & 0.45 & 2.30 & 8.70 & 2.97 \\
\hline Cyperus distans L.f. & 2 & 1 & 0.9 & 0.4 & 20 & 0.05 & 2.30 & 4.35 & 1.69 \\
\hline Paspalum conjugatum P.J.Bergius & 2 & 1 & 4.7 & 0.4 & 20 & 0.25 & 2.30 & 4.35 & 1.79 \\
\hline Pennisetum purpureum Schumach. & 2 & 1 & 29.5 & 0.4 & 20 & 1.59 & 2.30 & 4.35 & 2.46 \\
\hline Setaria palmifolia (J.Koenig) Stapf & 1 & 1 & 12.8 & 0.2 & 20 & 0.69 & 1.15 & 4.35 & 1.72 \\
\hline Tithonia diversifolia (Hemsl.) A.Gray & 2 & 2 & 88.1 & 0.4 & 40 & 4.75 & 2.30 & 8.70 & 5.12 \\
\hline
\end{tabular}

Table 4. Aquatic macrophytes in Bolo Creek of Balili River, Philippines

\begin{tabular}{|c|c|c|c|c|c|c|c|c|c|}
\hline Species name & ni & $\mathbf{J i}$ & ODW & Di & $\mathbf{F i}$ & RDWi & RDi & RFi & IV \\
\hline Ageratum conyzoides (L.) L. & 2 & 1 & 3.5 & 0.4 & 20 & 0.16 & 0.66 & 1.96 & 0.74 \\
\hline Alternanthera sessilis (L.)R.Br. ex DC. & 14 & 5 & 92.9 & 2.8 & 100 & 4.27 & 4.65 & 9.8 & 5.75 \\
\hline Amaranthus spinosus L. & 8 & 4 & 66.6 & 1.6 & 80 & 3.06 & 2.66 & 7.84 & 4.16 \\
\hline Bidens pilosa $\mathrm{L}$ & 15 & 2 & 100 & 3 & 40 & 4.6 & 4.98 & 3.92 & 4.52 \\
\hline Brugmansia versicolor Lagerh. & 1 & 1 & 3.1 & 0.2 & 20 & 0.14 & 0.33 & 1.96 & 0.64 \\
\hline Carica papaya $\mathrm{L}$ & 1 & 1 & 2.3 & 0.2 & 20 & 0.11 & 0.33 & 1.96 & 0.63 \\
\hline Commelina diffusa Burm.f. & 44 & 5 & 242.5 & 8.8 & 100 & 11.15 & 14.62 & 9.8 & 11.68 \\
\hline Cynodon dactylon (L.) Pers. & 40 & 3 & 927.4 & 8 & 60 & 42.64 & 13.29 & 5.88 & 26.11 \\
\hline Cyperus distans L.f. & 1 & 1 & 4.2 & 0.2 & 20 & 0.19 & 0.33 & 1.96 & 0.67 \\
\hline Eleusine indica (L.) Gaertn. & 5 & 2 & 13.6 & 1 & 40 & 0.63 & 1.66 & 3.92 & 1.71 \\
\hline Galinsoga parviflora Cav. & 40 & 1 & 137 & 8 & 20 & 6.3 & 13.29 & 1.96 & 6.96 \\
\hline Impatiens balsamina L. & 1 & 1 & 2.3 & 0.2 & 20 & 0.11 & 0.33 & 1.96 & 0.63 \\
\hline Melothria pendula L. & 4 & 2 & 7.7 & 0.8 & 40 & 0.35 & 1.33 & 3.92 & 1.49 \\
\hline Nasturtium officinale R.Br. & 6 & 2 & 17.1 & 1.2 & 40 & 0.79 & 1.99 & 3.92 & 1.87 \\
\hline Pennisetum purpureum Schumach. & 1 & 1 & 138.8 & 0.2 & 20 & 6.38 & 0.33 & 1.96 & 3.76 \\
\hline Persicaria glabra (Willd.) M.Gómez & 8 & 2 & 52.3 & 1.6 & 40 & 2.4 & 2.66 & 3.92 & 2.85 \\
\hline Plantago major L. & 1 & 1 & 23.7 & 0.2 & 20 & 1.09 & 0.33 & 1.96 & 1.12 \\
\hline Rorippa indica (L.) Hiern & 5 & 2 & 1.6 & 1 & 40 & 0.07 & 1.66 & 3.92 & 1.43 \\
\hline Rumex obtusifolius L. & 1 & 1 & 28.6 & 0.2 & 20 & 1.31 & 0.33 & 1.96 & 1.23 \\
\hline Setaria palmifolia (J.Koenig) Stapf & 5 & 2 & 1.5 & 1 & 40 & 0.07 & 1.66 & 3.92 & 1.43 \\
\hline Solanum americanum Mill. & 80 & 3 & 263.7 & 16 & 60 & 12.12 & 26.58 & 5.88 & 14.18 \\
\hline Sonchus oleraceus (L.) L. & 1 & 1 & 2 & 0.2 & 20 & 0.09 & 0.33 & 1.96 & 0.62 \\
\hline Youngia japonica (L.) DC. & 1 & 1 & 1.3 & 0.2 & 20 & 0.06 & 0.33 & 1.96 & 0.6 \\
\hline
\end{tabular}

The dominant plants in the littoral zone of the river were noxious weeds. In fact, these plants were commonly included in several weed manuals (Pancho 1983; Pancho and Obien 1983, 1995) and E. indica, P. purpureum, $C$. dactylon and $C$. diffusa were named among the world's worst weeds (Holm et al. 1977). These plants were fast growing and have high tolerance to different environmental conditions including pollution. It could be generalized that these plants were not simply surviving in the littoral zone but are thriving as they were observably robust. The success of weeds in the area could be attributed to their stolon/rhizome which enables them to colonize exposed area rapidly. Also, the moist condition and occasional flooding favour rooting at their nodes thus hastening their reproduction asexually.
The plants inventoried in the study were very different from those documented by Aguilar \& Buot (2003) and Vicencio \& Buot (2017) in Laguna Bay where three forms of macrophytes in the lake were determined. In contrast, only one form of macrophytes, which is emergent, was documented in Balili River. Also, these emergent macrophytes are not permanently inundated but only during heavy rains of rainy season. Our inventory of macrophytes in Balili River was more comparable with the inventory of Molawin Creek, Laguna by Torrefiel and Buot (2017). Of the 38 species documented in the study, 10 of these also occur in Molawin Creek. This shows that freshwater ecosystems in the country are highly unique in terms of biodiversity.

Diversity indices such as Simpson's, Margalef's and Shannon-Wiener's were also computed in the three 
sampling stations (Figure 3). Margalef's indices were relatively high except in Mamaga Creek. However, Shannon-Wiener indices were low ranging from 0.85 to 2.39 with the lowest value recorded in Mamaga Creeek and highest value in Bolo Creek. Shannon-Wiener's index is generally between 1.5 and 3.5 in most ecological studies with higher number indicating greater species richness and evenness (Fernando 1988). The higher index of Bolo Creek could be attributed to its relatively even distribution of individuals per species. On the other hand, Simpson's index ranged from 0 to 1 with higher values indicating presence of a dominant species. Mamaga Creek registered the highest Simpson's index of 0.22 indicative of the dominance of $C$. dactylon in the creek. Overall, Balili River registered a Simpson's index of 0.054, Margalef's index of 5.56, Shannon-Wiener's index of 1.66 and evenness of 0.249 . These values were comparable with the earlier diversity assessment in the same river by Napaldet and Bout (2017) except for Margalef's index which was much lower at 1.72 . The difference could be directly attributed to the higher species richness recorded in this study.

On the other hand, Jaccard's index of similarity showed that the main stream was more alike with Bolo Creek in terms of species composition than with Mamaga Creek (Table 5). Macrophytes common in all three sites are Alternanthera sessilis, Crassocephalum crepidioides, Cynodon dactylon, Cyperus distans and Pennisetum purpureum. The greater similarity between the main stream and Bolo Creek is just a consequence of their higher species richness. Mamaga Creek is the smallest among the three with much lesser riparian area where macrophytes could grow.

The result of inventory showed wealth of available plants that can utilized for phytoremediation of Balili River. The diversity indices, on the other hand, showed the current state of the river biodiversity-wise. Further, these indices also hinted the presence of dominant and widely- distributed macrophytes which are traits of a prospective phytoremediator. The dominance of Pennisetum purpureum, Eleusine indica and Amaranthus spinosus in the river makes them ideal prospect for phytoremediation of Balili River. Their dominance was not just based on population counts but also on biomass. Furthermore, these weeds have deep and more extensive roots compared with the other dominant macrophytes like $C$. dactylon and $A$. sessilis. These two are also dominant particularly in the two tributaries but their root systems are observably shorter. These satisfy the recommended traits of an efficient phytoremediator namely local, dominant plant with high biomass and deep extensive root system (Moffat 1995 and EPA 2000).

Moreover, some studies have already documented the phytoremedation potential of the above-mentioned three macrophytes. Pennisetum purpureum was cited to be good phytoremediator of soils contaminated by $\mathrm{Cd}, \mathrm{Zn}, \mathrm{Cs}$ (Zhang et. al. 2010 \& 2014), petroleum hydrocarbon (Ayotamuno et al. 2006) and P (Silveira et al. 2013). On the other hand, Eleusine indica was documented as phytostabilizer or good metal excluder at best (Merkl et al. 2005) but Lum et al. (2014) found the plant a good phytostabilizer for $\mathrm{Cu}$. Lastly, Amaranthus spinosus was found suitable for $\mathrm{Cu}, \mathrm{Zn}, \mathrm{Cr}, \mathrm{Pb}$, and $\mathrm{Cd}$ accumulation and translocation (Chinmayee et al. 2012). It's now a matter of evaluating their performance in constructed wetland set-ups for phytoremedation of wastewaters like that of Balili River.

Table 5. Jaccard's index of similarity (\%) among stations

\begin{tabular}{lll}
\hline & Main stream & Mamaga Creek \\
\hline Mamaga Creek & 26.67 & \\
Bolo Creek & 41.18 & 24.14 \\
\hline
\end{tabular}

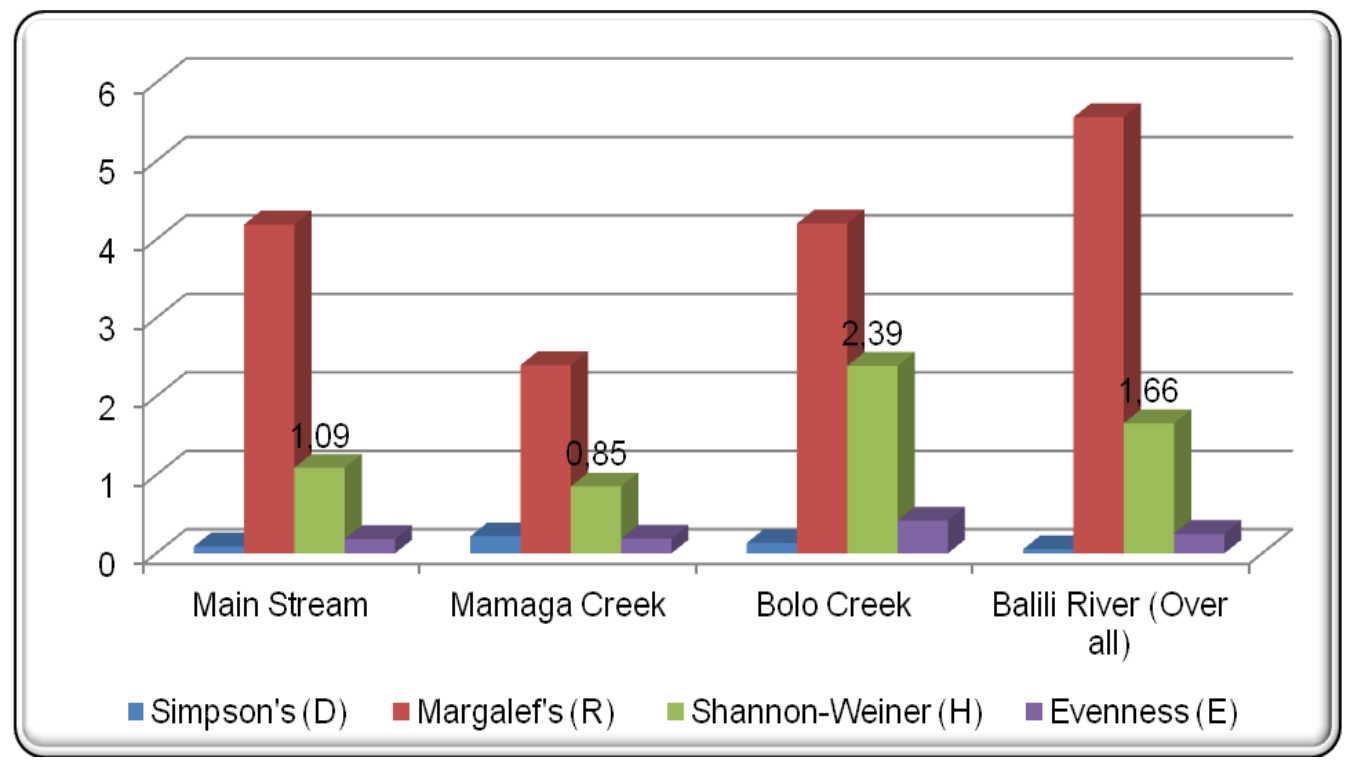

Figure 3. Diversity indices of Balili River, Philippines 
A total of 38 species of macrophytes under 37 genera and 19 families were inventoried in Balili River. In the main stream, 26 species were determined while 12 in Mamaga Creek and 25 in Bolo Creek. The main stream was dominated by Pennisetum purpureum, Eleusine indica, Amaranthus spinosus, Alternanthera sessilis, Solanum nigrum and Cynodon dactylon. Mamaga Creek was dominated by $C$. dactylon and A. sessilis while Bolo Creek by $C$. dactylon, $S$. nigrum and $C$. diffusa. These shows that species composition and dominance could vary even in sites of close proximity. In terms of species richness, family Asteraceae was the most represented with 12 species followed by Poaceae with 5. However, in terms of dominance, the story is different. The dominant macrophytes of Balili River were species of family Poaceae (Pennisetum purpureum, Eleusine indica and Cynodon dactylon), Amaranthaceae (Amaranthus spinosus and Alternanthera sessilis), Solanaceae (Solanum americanum) and Commelinaceae (Commelina diffusa). Macrophytes inventoried in Balili River were very different than those documented by Aguilar and Buot (2003) in Laguna Bay which shows the high uniqueness of freshwater ecosystems of the country in terms of biodiversity. Thus, more biodiversity inventories are encouraged to better account for the country's biodiversity particularly in less prioritized areas.

\section{ACKNOWLEDGEMENTS}

This study is part of the $\mathrm{PhD}$ dissertation titled, "Phytoremediation Performance of Aquatic Macrophytes of Balili River in A Pilot-Scale Constructed Wetland" funded by SEARCA thru their PHD Research Program and DOST-ASTHRDP through Student Research Support Fund (SRSF). The authors would also to express their appreciation to all individuals who extended help of any kind in making this work possible. Special mention to Edgar Alimambo for all the help during the data gathering part and to Ma'am Maricel Guron for the maps. Thank you and to God be the glory!

\section{REFERENCES}

Akratos CS, Tsihrintzis VA. 2007. Effect of temperature, HRT, vegetation and porous media on removal efficiency of pilot-scale horizontal subsurface flow constructed wetlands. Ecol Eng 29: 173-191.

Aro S. 2011. Balili River to be designated as Water Quality Management Area possible. PIA Press Release. Philippine Information Agency. Retrieved 13 January 2015.

Aguilar NO, Buot IE. 2003. Aquatic Macrophytes of Laguna De Bay, Luzon Island, Philippines. USM R \& D. 11(2): 110-116.

Co's Digital Flora. Angiosperm https://www.philippineplants.org/.

Coppini E, Masi F. 2006. Pilot-Scale Constructed Wetlands (Horizontal Subsurface Flow and Free Water System) For Tertiary Treatment in a
Textile Wastewater Treatment Plant. IWA Specialist Group on Use of Macrophytes in Water Pollution Control: Newsletter 31: 24-30.

[EPA] Environmental Protection Agency. 2000. Introduction to Phytoremediation. Washington: U.S. Environmental Protection Agency. EPA/600/R-99/107.

Fernando ES. 1998. Forest formations and flora of the Philippines: Handout in FBS 21. (Unpublished).

Hoddinott BC. 2006. Horizontal subsurface flow constructed wetlands for on-site wastewater treatment [Accessed on May 11, 2015]. www.loganhealth.org/assets/HSSFCWs.pdf.

Holm GH, Plucknett DL, Pancho JV, Herberger JP. 1977. The World's Worst Weeds: Distribution and Biology, University of Hawaii Press, Honolulu, Hawaii 609 p. [USA].

Hughes AR, Byrnes JE, Kimbro DL, Stachowicz JJ. 2007. Reciprocal relationships and potential feedbacks between biodiversity and disturbance. Ecol Lett 10: 849-864.

Jaccard P. 1908. Nouvelles recherches sur la distribu- tion florale. Bull Soc Vaudoise Sci Nat 44: 223-270.

Langenberger G. 2004. A Review of Research on Philippine Forest Vegetation, particularly Work since 1990. Agham Mindanaw 2:11-24.

Margalef R. 1958. Temporal Succession and Spatial Heterogeneity in Phytoplankton. In: Perspectives in Marine Biology, Buzzati-Traverso (ed.). Univ Calif Press, Berkeley, pp. 323-347.

Moffat AS. 1995. Plants proving their worth in toxic metal cleanup. Science 269: 302-303

Napaldet JT, Buot Jr IE. 2017. Floral diversity assessment of Balili River as potential phytoremediators. J Wetl Biodivers 7: 17-28.

Palangchao H. 2011. MOU inked in bid to save Balili River system. Baguio Midland Courier. Retrieved 13 January 2015.

Pancho JV. 1983. Weeds of Vegetable Farms in La Trinidad, Benguet Philippines, In: Weed Control in Tropical Crops II, p. 1-8.

Pancho JV, Gruezo WSm. 1983. Vascular flora of Mount Makiling and Vicinity (Luzon: Philippines) Part 1. Kalikasan, The Philippine J Biol, Suppl 1, Kalikasan Press, Manila.

Pancho JV, Gruezo WSm. 2006.Vascular Flora of Mount Makiling and Vicinity (Luzon: Philippines) Part 2. National Academy of Science and Technology (NAST) Philippines, Department of Science and Technology, Bicutan, Taguig City and Institute of Biological Sciences, College of Arts and Sciences, University of the Philippines Los Banos, College, Laguna, Philippines (Publishers), 626 p.

Pancho JV, Gruezo WSm. 2009. Vascular Flora of Mount Makiling and Vicinity (Luzon: Philippines) Part 3. Philippine Agric Sci 92 (Suppl. 1): S1-S496.

Pancho JV, Gruezo WSm. 2012. Vascular Flora of Mount Makiling and Vicinity (Luzon: Philippines) Part 4. National Academy of Science and Technology (NAST) Philippines, Department of Science and Technology, Bicutan, Taguig City and Institute of Biological Sciences, College of Arts and Sciences, University of the Philippines Los Banos, College, Laguna, Philippines (Publishers), 405 p.

Pancho JV, Obien SR. 1983. Manual of Weeds of Tabacco Farms in the Philippines. New Mercury Printing Press, Quezon City, 298 p. [Philippines].

Pancho JV, Obien SR. 1995. Manual of Ricefield Weeds in the Philippines, Philippine Rice Research Institute, Muñoz, Nueva Ecija, Philippines, $543 \mathrm{p}$.

Shannon CE, Wiener W. 1949. The Mathematical Theory of Communication. University of Illinois Press, Urbana 177 p.

Simpson EH. 1949. Measurement of diversity. Nature 163:688

Thomaz SM, da Cunha ER. 2010. The role of macrophytes in habitat structuring in aquatic ecosystems: methods of measurement, causes and consequences on animal assemblages' composition and biodiversity. Acta Limnologica Brasiliensia 22:2.

Torrefiel JT, Buot Jr IE. 2017. Weed species composition in the riparian zone of Molawin River, Laguna, Philippines. J Wetl Biodivers 7: 5773 .

Vicencio EJM, Buot Jr IE. 2017. Aquatic weed flora on the Southwest Lakeside of Laguna De Bay. J Wetl Biodivers 7: 75-90. 